\title{
Association between shift work, salivary cortisol levels, stress and fatigue in nurses: integrative review
}

\author{
Associação entre turnos de trabalho, níveis de cortisol salivar, estresse e fadiga em enfermeiros: revisão \\ integrativa \\ Asociación entre turnos de trabajo, niveles de cortisol salivar, estrés y fatiga en enfermeros: revisión \\ integrativa
}

Dnieber Chagas de Assis ${ }^{1}$

Deisy Vivian de Resende ${ }^{1}$

Maria Helena Palucci Marziale²

1. Universidade Federal de Uberlândia.

Uberlândia, MG, Brazil.

2. Universidade de São Paulo. Ribeirão Preto, SP, Brazil
Corresponding author Dnieber Chagas de Assis. E-mail: dnieber@ufu.br

Submitted on 05/08/2017. Accepted on 11/18/2017.

DOI: 10.1590/2177-9465-EAN-2017-0125

\begin{abstract}
Objective: This study aimed to identify scientific evidence about the association between shift work and changes on the cortiso circadian rhythm, stress and fatigue in nurses. Method: We found 1046 articles published between 2006 and 2016 in the Medline, LILACS, WOS, Scopus and SciElo databases, three articles were included in this review. Results: The studies presented low methodological rigor and inconclusive results due to methodological diversity and small sample size. Thus, based on the existing literature, it was not possible to determine the existence of a significant association between shift work, cortisol levels, stress and fatigue in nurses. Conclusion: The strategies required to obtain reliable and comparable results include the adoption of standard methods of participant selection, sample collection and analysis, and use of validated psychometric instruments.
\end{abstract}

Keywords: Stress; Cortisol; Fatigue; Nurses; Shift Work.

\section{Resumo}

Objetivo: Identificar evidências científicas sobre a associação entre o trabalho em turnos e alterações do ritmo circadiano do cortisol, índices de estresse e fadiga em trabalhadores de enfermagem. Método: Foram identificados 1.046 artigos publicados entre 2006 e 2016 nas bases Medline, LILACS, WOS, Scopus e SciElo, dos quais três atenderam aos critérios de inclusão. Resultado: Os estudos apresentaram baixo rigor metodológico e resultados inconclusivos em virtude da diversidade metodológica e baixo número amostral. Dessa forma, com base na literatura existente, não foi possível determinar a existência de associação significativa entre esquemas de trabalho em turnos, trabalho de enfermagem e alterações do ritmo circadiano do cortisol, índices de estresse e fadiga. Conclusão: As estratégias necessárias para a obtenção de resultados confiáveis e passíveis de comparação incluem a adoção de métodos padronizados de seleção dos participantes, coleta e análise das amostras e utilização de instrumentos psicométricos validados.

Palavras-chave: Estresse; Cortisol; Fadiga; Enfermeiros; Trabalho em Turnos.

\section{Resumen}

Objetivo: Identificar la evidencia científica sobre la asociación entre el trabajo por turnos y los cambios en el ritmo circadiano del cortisol, el estrés y la fatiga en las enfermeras. Método: Se identificaron 1046 artículos publicados entre 2006 y 2016 en las bases Medline, LILACS, WOS, Scopus y SciElo, de los cuales três cumplieron los criterios de inclusión. Resultado: Los estudios presentaron bajo rigor metodológico y resultados inconclusos en virtud de la diversidad metodológica y bajo número de muestras. De esta forma, con base en la literatura existente, no fue posible determinar la existencia de asociación significativa entre esquemas de trabajo en turnos, trabajo de enfermería y alteraciones del ritmo circadiano del cortisol, índices de estrés y fatiga. Conclusión: Las estrategias necesarias para obtener resultados confiables y comparables incluyen la adopción de métodos estandarizados para la selección de los participantes, la recolección y el análisis de las muestras y el uso de instrumentos psicométricos validados.

Palabras clave: Estrés; Cortisol; Fatiga; Enfermeros; Trabajo por Turnos. 


\section{INTRODUCTION}

In human beings, cortisol is the main glucocorticoid hormone produced by the adrenal glands after the activation of hypothalamo-hypophyseal-adrenal axis ( $\mathrm{HHA})$. This hormone acts the main role in a multitude of biological processes, such as energy metabolism, blood pressure stability, immune modulation, cognitive and memory regulation, and stress response ${ }^{1,2}$. Its secretion happens in deep circadian rhythmicity, with highest levels at approximately thirty minutes after awakening, and gradual decrease throughout the day. However, physical or psychological stress agents, many pharmaceuticals, as well as genetic and sociodemographic factors are able to alter cortisol secretion rhythm, either stimulating or suppressing the $\mathrm{HHA}$ axis $^{3,4}$.

The use of saliva as a diagnosis fluid is a relatively new practice and, although many biomarkers can be analyzed, including heavy metals, enzymes and DNA, measuring cortisol levels as a neurobiological stress and fatigue marker has proven itself promising, with plenty of available commercial tests ${ }^{5-7}$. Salivary cortisol is the free and biologically active form of this hormone, and sample collection is simple, safe and non-invasive, as it can be made even in the participant's workplace. ${ }^{8}$

The evaluation of occupational stress effects on salivary secretion of cortisol has been presenting inconclusive results, although many studies show higher activation of the HHA axis during workdays, when compared to weekends, in different kinds of workforce..$^{9-15}$ In addition, low cortisol levels upon awakening and daytime cortisol decrease have been considered predictors of fatigue, burnout and vital exhaustion. ${ }^{16-18}$ Nursing professionals, due to long working hours in assorted shifts, are specially susceptible to chronic stress and fatigue, whose consequences, on the long run, amount to desynchrony of the HHA axis and consequent physical and mental disease, work capability decrease, occupational accident increase, and absenteeism. ${ }^{19-22}$

Considering the aforementioned, the goal of this study was to identify, in Brazilian and international literature, scientific evidence on the correlation of work in shifts and alterations to cortisol circadian rhythm, stress levels, and fatigue in nursing workers.

\section{METHODS}

Integrative literature review, elaborated upon recommendations by Ganong ${ }^{23}$, which divide the research in six steps. On the first step, a guiding question was developed; on the second one, sample articles were selected; on the third step, the characteristics of the reviewed research were chosen; on the fourth one, findings were analyzed, according to the established inclusion and exclusion criteria; on the fifth step, results were interpreted; finally, on the sixth step, this article was written, aiming at publishing the results.
Investigation hypothesis:

- Is it possible to determine, based on literature, the existence of a relation between shift work routines, nursing work, and alterations to the circadian cortisol rhythm, stress levels, and fatigue?

For article research, the following databases were accessed: Medical Literature Analysis and Retrieval System Online (Medline); Literatura Latino-Americana e do Caribe em Ciências da Saúde (LILACS); Web of Science (WOS), Scopus and Scientific Electronic Library Online (SciElo).

Search headers in use were, in Portuguese and English: Cortisol OR Stress OR Fatigue AND Nursing AND Work shift, which are part of Descritores em Ciências da Saúde - DeCS and Medical Subject Headings - MeSH, observing the search criteria established in each database.

Inclusion criteria established for this study were: original papers resulting from quantitative approach studies and literature review articles, available on the databases, in English, Spanish or Portuguese, within a timeframe from January 2006 to October 2016, and which could offer information to answer the investigation hypothesis. Letters and editorials have been excluded from this research, as well as articles that were not fully available in the databases. Repeated papers upon different databases were accounted for only on the database with the highest number of valid entries. ${ }^{24}$

Data were collected with double search and upon reading of entire articles, followed by information records, a form adapted from the review studies instrument used by Rede Internacional de Enfermagem em Saúde Ocupacional - REDENSO. ${ }^{25}$ That instrument contains the following items: identification of the original paper, methodological characteristics of the study, evaluation of evidence levels according to the Melnyk and Fineout-Overholt ${ }^{26}$ scale, and evaluation of results found, as well as gaps and advances noticed through the study process.

Results are presented in descriptive form, according to the recommendations found in PRISMA (Preferred Reporting Items for Systematic Reviews and Meta-Analysis) ${ }^{26,27}$, upon use of charts, aiming at summarizing evidence of the relation between the levels of cortisol, stress and fatigue among nursing workforce employees, and the limitations presented by each study.

\section{RESULTS}

The initial search on databases identified 1,046 potentially relevant papers. Out of those, 165 matched the inclusion criteria and were read fully (Figure 1).

After reading and exclusion criteria matching, three papers were included in this study (Chart 1) due to their presenting evidence on the relation between cortisol levels and occupational stress or fatigue in nursing work shifts. Concerning evidence levels, the included articles presented level six of relevance, according to the Melnyk and Fineout-Overholt scale ${ }^{26}$. 


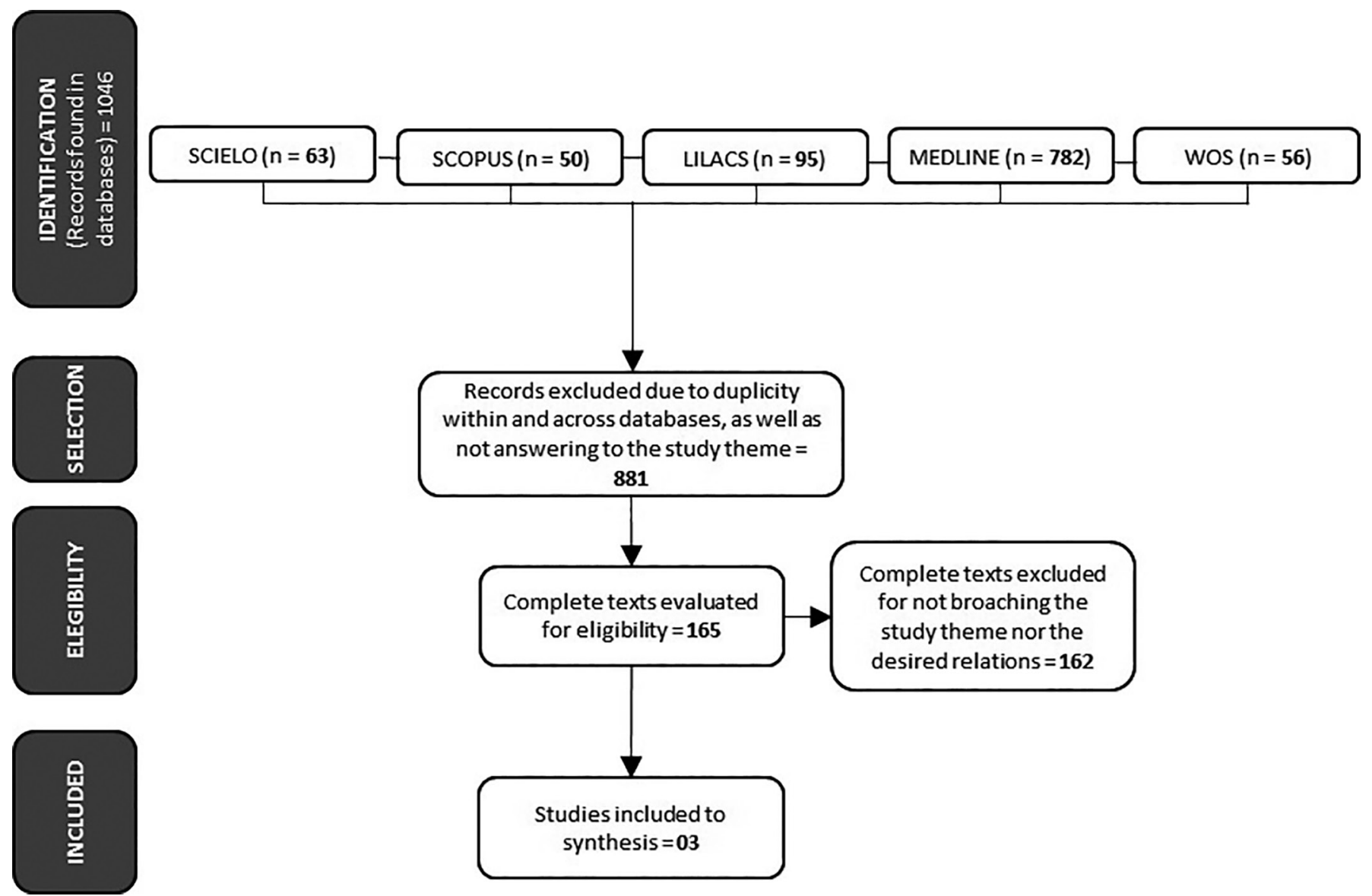

\section{DISCUSSION}

All the articles included in this review presented low evidence level in associating salivary cortisol with stress of fatigue among nursing workers. Only one study evaluated a possible relation between fatigue or cortisol levels and work shifts in nurses, finding, however, no remarkable results. ${ }^{28}$ In another study, nurses from the night shift presented alterations to the circadian pattern of cortisol secretion which were clinically associated to sleepiness, fatigue and sleep disorders. ${ }^{19}$

Concerning occupational stress, cortisol secretion and work shifts, the results were likewise inconclusive, whereas a study showed that salivary cortisol levels in workers presented typical secretion patterns, regardless of the work shift ${ }^{7}$, while, in other two studies, professionals working the night shift presented alterations on daily secretion of cortisol, though of no statistical relevance. 19,28 No articles were found which concomitantly evaluated fatigue, stress and salivary cortisol levels in nurses.

Different sample collection and cortisol analysis methods have been in use, attempting to identify the most representative measurement of the HHA axis. Variability of methodological designs may be a plausible explanation for the inconsistency of obtained results. Sample collection protocols in the selected studies varied from one to three days, and in only one study cortisol levels upon awakening were analyzed. ${ }^{7}$ Among the selected articles, only one of them analyzed saliva samples collected in two different days (workday and leave), whereas two studies analyzed samples provided in a single day.

Analyzed sample total throughout the day and sample collection moments also varied, so only one study analyzed a sample upon awakening. Literature data have shown an increase of result reliability when samples are analyzed for at least two consecutive days, instead of a higher number of samples in a day. ${ }^{5}$ Although there is no consensus regarding the best sampling strategy, higher cortisol responses after exposure to psychosocial stress are obtained in the morning, making cortisol response upon awakening (CAR) a promising measurement.

Patterns of cortisol secretion on the first hour upon awakening have been associated to fatigue, burnout, exhaustion, depressive symptoms and recovery of daily rhythm after working in shifts. ${ }^{29-33}$ In addition, there was no consensus regarding the evaluation of cortisol secretion, so two studies chose to analyze it in predetermined occasions ${ }^{19,28}$ and two used standard indexes of cortisol secretion such as CAR and the area under the curve $(\mathrm{AUC}){ }^{7}$

Another possible explanation for data inconsistency is the low sample number of the studies. The authors reported taking plentiful exclusion criteria, sample losses due to insufficient saliva 


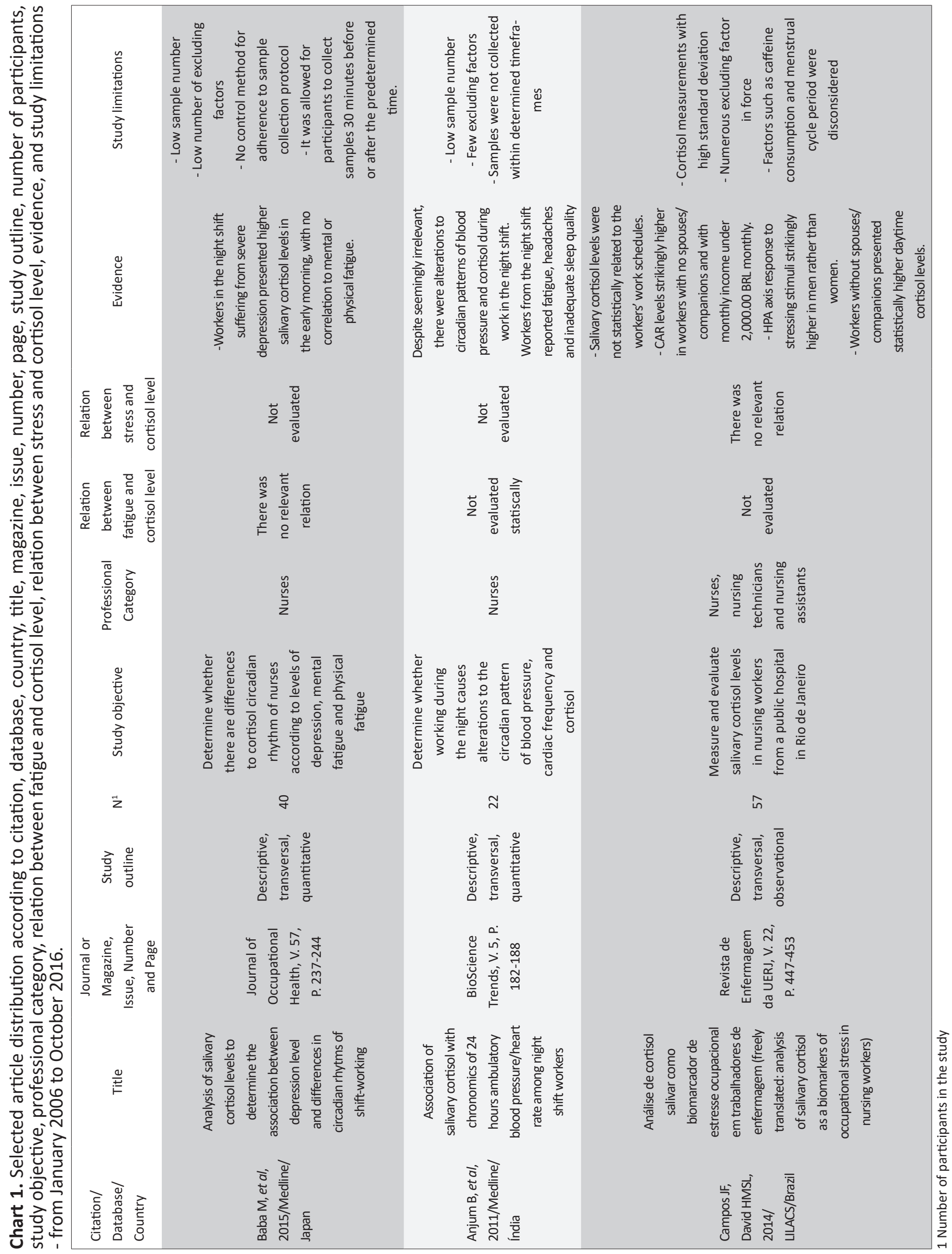


quantity, and a lack of adherence to sample collection protocol as the main causes for this situation. It is known that reliable cortisol measurements are hard to obtain, since the HHA axis responds sensibly to a variety of internal and external events. ${ }^{33-35}$

Given the high variability of intra and interindividual cortisol levels, control of the main confusing variables through statistical techniques and determination of exclusion criteria based on the investigation hypothesis tend to outcome in results that are more robust and susceptible to generalization. ${ }^{36-39}$ In the papers under analysis, there was no consensus regarding the consideration of interference factors on cortisol secretion, such as the use of contraception, caffeine and physical activity.

It is recommendable that, during the study planning phase, confusing variables be identified based on existing literature. The absence of control over those variables diminishes the power of statistical analysis and relations may not be duly identified. ${ }^{33,40}$

One of the greatest problems regarding saliva collection by the participants themselves is related to obtaining reliable samples, specially if they are obtained during the first hour upon awakening. During that time, cortisol levels vary extremely fast, so the adherence of participants to sample collection protocol becomes a determining factor for obtaining valid results. ${ }^{41}$

In the reviewed articles, the description of evaluation criteria to collection protocol adherence were direct, such as providing a notebook for each participant with collection instructions, ${ }^{19}$ or indirect, such as a minimum CAR of $2.5 \mathrm{nmol} / / .{ }^{7}$ countless studies in literature mention mechanisms to monitor adherence to sample collection protocols by participants, such as using electronic devices, sending telephone messages, and emphasizing the importance of the research.

Regardless of the criteria in use, it is known that a participant's self report about the time of saliva collection, on itself, is not enough to ensure reliable samples. Such samples are more easily obtained when the participants are informed that their samples will be objectively monitored. . $^{33,42,43}$

Evaluation of mental stress agents in the workplace requires using validated psychometric scales. None of the studies used a validated scale, nor one specific for analyzing stress in nurses, neither was it possible to determine whether records about stress indexes unrelated to work, such as depression, anxiety, personality traits and coping mechanisms, were made.

Despite its inconclusive results, this review has shown that there is evidence pointing to work in shifts as a factor on the desynchrony of the HHA axis in nursing professionals. Workers in the night shift presented a striking alteration to cortisol circadian cycle and reported higher fatigue and sleepiness after work. ${ }^{19,28}$ Additional studies, using a greater number of participants and standardized methodologies, are necessary in order to confirm these findings. Considering that fatigue and stress negatively affect workers' health, performance and patient care, identifying factors causing inconsistencies in the findings is prerequisite for obtaining valid results in occupational stress studies. Data herein presented provide material for development of research whose results may allow the implementation of adequate organizational interventions to workplaces.

\section{FINAL REMARKS}

Despite the hypothesis that working in shifts is an important element in the relation between cortisol, stress and fatigue levels in nursing professionals, it has not been possible to determine yet a consistent relation between those variables. The findings of this review suggest that studies evaluating the relation between occupational stress agents and psychobiological variables include standardized methodological strategies and higher statistical potential, in order to define possible causality relations.

Nevertheless, results herein presented must be interpreted, considering some limitations. Firstly, articles written in languages other than Portuguese, Spanish and English were not included to the analysis, what may have decreased the sample field. Furthermore, transversal outlining of the articles may have been an impeding factor in determining a consistent relation between the variables.

\section{REFERENCES}

1. Chrousos GP, Kino T. Glucocorticoid action networks and complex psychiatric and/or somatic disorders. Stress [Internet]. 2007 Jun; [cited 2016 Dec 4]; 10(2):213-9. Available from: http://www.tandfonline.com/ doi/abs/10.1080/10253890701292119?journalCode=ists20. DOI 10.1080/10253890701292119

2. Hellhammer DH, Wüst S, Kudielka BM. Salivary cortisol as a biomarker in stress research. Psychoneuroendocrinology [Internet]. 2009 Feb [cited 2016 Nov 23]; 34(2):163-71. Available from: http://www.psyneuenjournal.com/article/S0306-4530(08)00299-0/abstract. DOI: 10.1016/j. psyneuen.2008.10.026

3. Nicolaides NC, Charmandari E, Kino T, Chrousos GP. Stress-Related and Circadian Secretion and Target Tissue Actions of Glucocorticoids: Impact on Health. Front Endocrinol [Internet]. 2017 Apr; [cited 2017 Jun 28]; 8:1-11. Available from: https://www.ncbi.nlm.nih.gov/pmc/articles/ PMC5408025/pdf/fendo-08-00070.pdf. DOI: 10.3389/fendo.2017.00070

4. Kudielka BM, Buchtal J, Unde A, Wüst S. Circadian cortisol profiles and psychological self-reports in shift workers with and without recent change in the shift rotation system. Biol Psychol [Internet]. 2007 Jan; [cited 2016 Dec 22]; 74(1):92-103. Available from: http://www. sciencedirect.com/science/article/pii/S0301051106001955. DOI 10.1016/j.biopsycho.2006.08.008

5. Inder WJ, Dimeski G, Russell A. Measurement of salivary cortisol in 2012 - laboratory techniques and clinical indications. Clin Endocrinol (Oxf) [Internet]. 2012 Nov; [cited 2016 Oct 12]; 77(5):645-51. Available from: http://onlinelibrary.wiley.com/doi/10.1111/j.1365-2265.2012.04508.x/ abstract;jsessionid=541C53C5822A66A5294A448CA49662B2.f02t04. DOI: $10.1111 / \mathrm{j} .1365-2265.2012 .04508 . x$

6. Powell DJH, Liossi C, Moss-Morris R, Schlotz W. Unstimulated cortisol secretory activity in everyday life and its relationship with fatigue and chronic fatigue syndrome: A systematic review and subset metaanalysis. Psychoneuroendocrinology [Internet]. 2013 Nov; [cited 2016 Nov 29]; 38(11):2405-22. Available from: http://www.psyneuenjournal.com/article/S0306-4530(13)00254-0/abstract. DOI: 10.1016/j. psyneuen.2013.07.004

7. Campos JF, David HMSL. Analysis of salivary cortisol as stress biomarker in nursing workers. Rev Enferm UERJ [Internet]. $2014 \mathrm{Jul} / \mathrm{Aug}$ [cited 2016 Dec 3];22(4):447-53. Available from: http://www.facenf.uerj. br/v22n4/v22n4a02.pdf. DOI: 10.1590/S0080-623420130000500025 
8. Bozovic D, Racic M, Ivkovic N.Salivary Cortisol Levels as a Biological Marker of Stress Reaction. Med Arch [Internet]. 2013 Jan; [cited 2016 Oct 22]; 67(5):374-7. Available from: http://www.academia. edu/11396263/Salivary_Cortisol_Levels_as_a_Biological_Marker_ of_Stress_Reaction. DOI: 10.5455/medarh.2013.67.371-374

9. Steptoe A, Hamer M, Lin J, Blackburn EH, Erusalimsky JD. The Longitudinal Relationship Between Cortisol Responses to Mental Stress and Leukocyte Telomere Attrition. J Clin Endocrinol Metab [Internet]. 2017 Mar; [cited 2017 Jun 27]; 102(3):962-9. Available from: https://academic.oup.com/jcem/article-lookup/doi/10.1210/jc.20163035. DOI: 10.1210/jc.2016-3035

10. Wolkow A, Ferguson S, Aisbett B, Main L. Effects of work-related sleep restriction on acute physiological and psychological stress responses and their interactions: A review among emergency service personnel. Int J Occup Med Environ Health [Internet]. 2015; [cited 2017 Jun 26]; 28(2):183-208. Available from: http://ijomeh.eu/pdf-19792057 ?filename=Effects\%20of\%20work-related.pdf. DOI: 10.13075/ ijomeh.1896.00227

11. Garcez A, Weiderpass E, Canuto R, Lecke SB, Spritzer PM, Pattussi MP, et al. Salivary Cortisol, Perceived Stress, and Metabolic Syndrome: A Matched Case-Control Study in Female Shift Workers. Horm Metab Res [Internet]. 2017; [cited 2017 Jun 22]; 49(7):510-9. Available from: https://www.thieme-connect.com/DOI/DOI?10.1055/s-0043-101822. DOI: 10.1055/s-0043-101822

12. Thorn L, Evans P, Cannon A, Hucklebridge F, Clow A. Seasonal differences in the diurnal pattern of cortisol secretion in healthy participants and those with self-assessed seasonal affective disorder. Psychoneuroendocrinology [Internet]. 2011 Jul; [cited 2016 Oct 12]; 36(6):816-23. Available from: http://www.sciencedirect.com/science/ article/pii/S0306453010002817.DOI: 10.1016/j.psyneuen.2010.11.003

13. Maina G, Palmas A, Bovenzi M, Filon FL.Salivary cortisol and psychosocial hazards at work. Am J Ind Med [Internet]. 2009 Mar; [cited 2016 Nov 22]; 52(3):251-60. Available from: http://onlinelibrary.wiley. com/doi/10.1002/ajim.20659/abstract. DOI: 10.1002/ajim.20659

14. Kim KJ, Chung JW, Park S, Shin JT. Psychophysiological stress response during competition between elite and non-elite Korean Junior Golfers. Int J Sports Med [Internet]. 2009; [cited 2016 Oct 12]; 30(7):503-8. Available from: https://www.thieme-connect.com/DOI/ DOI?10.1055/s-0029-1202338. DOI: 10.1055/s-0029-1202338

15. Moustaka E, Maria M, Constantinidis TC. Measuring occupational stress and HRA axis dysregulation among healthy workers by salivary cortisol levels. J Adv Med Med Res [Internet]. 2015 Jan; [cited 2016 Nov 3]; 6(11):1040-51. Available from: http://www.journalrepository.org/media/ journals/BJMMR_12/2015/Jan/Maria6112014BJMMR15530.pdf.DOI: 10.9734/BJMMR/2015/15530

16. Grossi G, Perski A, Osika W, Savic I. Stress-related exhaustion disorder-clinical manifestation of burnout? A review of assessment methods, sleep impairments, cognitive disturbances, and neuro-biological and physiological changes in clinical burnout. Scand J Psychol [Internet]. 2015 Dec; [cited 2017 Jun 23]; 56(6):626-36. Available from: http:// onlinelibrary.wiley.com/doi/10.1111/sjop.12251/pdf. DOI: 10.1111/ sjop. 12251

17. ter Wolbeek M, van Doornen LJP, Coffeng LE, Kavelaars A, Heijnen CJ. Cortisol and severe fatigue: A longitudinal study in adolescent girls. Psychoneuroendocrinology [Internet]. 2007 Feb; [cited 2016 Nov 21]; 32(2):171-82. Available from: http://www.sciencedirect.com/science/ article/pii/S0306453006002216. DOI: 10.1016/j.psyneuen.2006.12.003

18. Kumari M, Badrick E, Ferrie J, Perski A, Marmot M, Chandola T.Selfreported sleep duration and sleep disturbance are independently associated with cortisol secretion in the Whitehall II study. J Clin Endocrinol Metab [Internet]. 2009 Dec; [cited 2016 Nov 22]; 94(12):4801-9. Available from: https://www.ncbi.nlm.nih.gov/pmc/ articles/PMC2795654/. DOI: 10.1210/jc.2009-0555

19. Anjum B, Verma NS, Tiwari S, Singh R, Mahdi AA, Singh RB, et al.Association of salivary cortisol with chronomics of 24 hours ambulatory blood pressure/heart rate among night shift workers. Biosci Trends [Internet]. 2011 Aug; [cited 2016 Dec 14]; 5(4):182-8. Available from: http://www.biosciencetrends.com/getabstract.php?id=450. DOI: 10.5582/bst.2011.v5.4.182

20. Vasconcelos S, Marqueze E, Gonçalves L, Lemos L, Araújo L, Fischer FM, et al.Morbidity among nursing personnel and its association with working conditions and work organization. Work [Internet]. 2012; [cited 2016 Dec 14]; 41(Suppl 1):3732-7. Available from: http://content. iospress.com/articles/work/wor0087. DOI: 10.3233/WOR-2012-00873732

21. Niu SF, Chung MH, Chu H, Tsai JC, Lin CC, Liao YM, et al. Differences in cortisol profiles and circadian adjustment time between nurses working night shifts and regular day shifts: A prospective longitudinal study. Int J Nurs Stud [Internet]. 2015 Jul; [cited 2016 Dec 13]; 52(7):1193-201. Available from: http://www.journalofnursingstudies.com/article/S00207489(15)00102-9/abstract. DOI: 10.1016/j.ijnurstu.2015.04.001

22. Bracci M, Ciarapica V, Copertaro A, Barbaresi M, Manzella N, Tomasetti $\mathrm{M}$, et al. Peripheral skin temperature and circadian biological clock in shift nurses after a day off. Int J Mol Sci [Internet]. 2016 May; [cited 2016 Dec 12]; 17(5):623. Available from: https://www.ncbi.nlm.nih.gov/pmc/ articles/PMC4881449/. DOI: 10.3390/ijms17050623

23. Ganong LH.Integrative reviews of nursing research. Res Nurs Health [Internet]. 1987 Feb; [cited 2017 Dec 18]; 10(1):1-11. Available from: https://www.ncbi.nlm.nih.gov/pubmed/?term=Ganong+LH.+Integrativ e+reviews+of+nursing+research.+Res+Nurs+Health.+1987+feb\%3B $+10(1) \% 3 \mathrm{~A} 1-11$

24. Batista DCS, Pimenta CAM. Semelhanças e diferenças da dor nas síndromes torácicas. Rev Gaúch Enferm [Internet]. 2008 Jun; [cited 2016 Dec 4]; 29(2):301-7. Available from: http://seer.ufrgs.br/index. php/RevistaGauchadeEnfermagem/article/view/5595

25. Marziale MHP. Instrumento para coleta de dados para revisão integrativa da literatura. Redenso Internacional. Ribeirão Preto, Brasil. 2015. Available from: http://gruposdepesquisa.eerp.usp.br/sites/ redenso/wp-content/uploads/sites/9/2016/04/Instrumiento-revisionde-la-litetarura-RedENSO-2017.pdf

26. Melnyk BM, Fineout-Overholt E. Making the case for evidence-based practice. In: Melnyk BM, Fineout-Overholt E. Evidence-based practice in nursing \& healthcare: a guide to best practice. Philadelphia: Lippincot Williams \& Wilkins; 2005. p. 3-24.

27. Liberati A, Altman DG, Tetzlaff J, Mulrow C, Gøtzsche PC, loannidis JPA, et al. The PRISMA statement for reporting systematic reviews and meta-analyses of studies that evaluate health care interventions: explanation and elaboration. PLoS Med [Internet]. 2009 Jul; [cited 2016 Aug 3]; 6(7):e1000100. Available from: http://journals.plos. org/plosmedicine/article?id=10.1371/journal.pmed.1000100. DOI: 10.1371/journal.pmed.1000100

28. Baba M, Ohkura M, Koga K, Nishiuchi K, Herrera CLR, Matsuse R, et al.Analysis of salivary cortisol levels to determine the association between depression level and differences in circadian rhythms of shiftworking nurses.J Occup Health [Internet]. 2015 Mar; [cited 2016 Aug 4]; 57(3):237-44. Available from: https://www.jstage.jst.go.jp/article/ joh/57/3/57_14-0079-OA/_article.DOI: 10.1539/joh.14-0079-OA

29. Violanti JM, Fekedulegn D, Andrew ME, Hartley TA, Charles LE, Miller $\mathrm{DB}$, et al. The impact of perceived intensity and frequency of police work occupational stressors on the cortisol awakening response (CAR): Findings from the BCOPS study. Psychoneuroendocrinology [Internet]. 2017 Jan; [cited 2017 Jun 25]; 75(1):124-31. Available from: http://www. psyneuen-journal.com/article/S0306-4530(16)30202-5/fulltext. DOI: 10.1016/j.psyneuen.2016.10.017

30. Gustafsson PE, Gustafsson PA, Ivarsson T, Nelson N. Diurnal cortiso levels and cortisol response in youths with obsessive e compulsive disorder. Neuropsychobiology [Internet]. 2008 Jun; [cited 2016 Dec 2]; 57(1-2):14-21. Available from: https://www.karger.com/Article/ Abstract/123117. DOI: 10.1159/000123117

31. Chida $Y$, Steptoe A. Cortisol awakening response and psychosocial factors: a systematic review and meta-analysis. Biol Psycho [Internet]. 2009 Mar; [cited 2016 Dec 1]; 80(3):265-78. Available from: https://www.ncbi.nlm.nih.gov/pubmed/19022335. DOI: 10.1016/j. biopsycho.2008.10.004 
32. Oosterholt BG, Maes JHR, Van der Linden D, Verbraak MJPM, Kompier MAJ.Burnout and cortisol: evidence for a lower cortisol awakening response in both clinical and non-clinical burnout. J Psychosom Res [Internet]. 2015 May; [cited 2016 Dec 01]; 78(5):445-51. Available from: http://www.jpsychores.com/article/S0022-3999(14)00383-3/abstract. DOI: 10.1016/j.jpsychores.2014.11.003

33. Kudielka BM, Gierens A, Hellhammer DH, Wüst S, Schlotz W. Salivary cortisol in ambulatory assessment--some dos, some don'ts, and some open questions. Psychosom Med [Internet]. 2012 May; [cited 2016 Dec 2]; 74(4):418-31. Available from: http://journals. Iww.com/psychosomaticmedicine/pages/articleviewer.aspx?year= 2012\&issue $=05000 \&$ article $=00011 \&$ type $=$ abstract. DOI: $10.1097 /$ PSY.0b013e31825434c7

34. Kudielka BM, Hellhammer DH, Wüst $\mathrm{S}$. Why do we respond so differently? Reviewing determinants of human salivary cortisol responses to challenge. Psychoneuroendocrinology [Internet].2009 Jan; [cited 2016 Dec 2]; 34(1):2-18. Available from: http://www.psyneuenjournal.com/article/S0306-4530(08)00264-3/abstract. DOI: 10.1016/j. psyneuen.2008.10.004

35. Saxbe DE, Repetti RL, Nishina A.Marital satisfaction, recovery from work, and diurnal cortisol among men and women. Health Psychology [Internet]. 2008 Jan; [cited 2016 Dec 22]; 27(1):15-25. Available from: http://psycnet.apa.org/journals/hea/27/1/15/. DOI: 10.1037/02786133.27.1.15

36. Thayer JF, Verkuil B, Brosschot JF, Kampschroer K, West A, Sterling C, et al. Effects of the Physical Work Environment on Physiological Measures of Stress. Eur J Cardiovasc Prev Rehabil [Internet]. 2010 Aug; [cited 2017 Jun 29]; 17(4):431-9. Available from: https://www.ncbi.nlm.nih.gov/pmc/ articles/PMC2917179/. DOI: 10.1097/HJR.0b013e328336923a

37. Lundberg U. Methods and applications of stress research. Technol Health Care [Internet]. 1995 Mar; [cited 2017 Dec 18]; 3(1):3-9. Available from: https://www.ncbi.nlm.nih.gov/pubmed/?term=Lundberg+U.+Methods+ and+applications+of+stress+research.+Technol+Health+Care.++1995 $+\operatorname{mar} \% 3 \mathrm{~B}+3(1) \% 3 \mathrm{~A} 3-9$
38. Stawski RS, Cichy KE, Piazza JR, Almeida DM. Associations among daily stressors and salivary cortisol: findings from the National Study of Daily Experiences. Psychoneuroendocrinology [Internet]. 2013 Nov; [cited 2017 Jun 29]; 38(11):2654-65. Available from: https:// www.ncbi.nlm.nih.gov/pmc/articles/PMC3914662/. DOI: 10.1016/j. psyneuen.2013.06.023

39. Kirschbaum C, Hellhammer DH. Salivary cortisol in psychobiological research: an overview. Neuropsychobiology [Internet]. 1989; [cited 2016 Nov 22]; 22(3):150-69. Available from: https://www.karger.com/Article/ Abstract/118611. DOI: 10.1159/000118611

40. Cozma S, Dima-Cozma LC, Ghiciuc CM, Pasquali V, Saponaro A, Patacchioli FR. Salivary cortisol and a-amylase: subclinical indicators of stress as cardiometabolic risk. Braz J Med Biol Res [Internet]. $2017 \mathrm{Feb}$ [cited 2017 Jun 27]; 50(2):e5577. Available from https://www.ncbi.nlm. nih.gov/pmc/articles/PMC5390531/.DOI: 10.1590/1414-431X20165577

41. Gumenyuk V, Roth T, Drake CL. Circadian phase, sleepiness, and light exposure assessment in night workers with and without shift work disorder. Chronobiol Int [Internet]. 2012 Aug [cited 2017 Jun 25]; 29(7):928-36. Available from: http://www.tandfonline.com/doi/ abs/10.3109/07420528.2012.699356?journalCode=icbi20. DOI: 10.3109/07420528.2012.699356

42. Kudielka BM, Broderick JE, Kirschbaum C. Compliance with saliva sampling protocols: electronic monitoring reveals invalid cortiso daytime profiles in noncompliant subjects. Psychosom Med [Internet] 2003 Mar/Apr; [cited 2016 Nov 12]; 65(2):313-9. Available from: http:// journals.Iww.com/psychosomaticmedicine/Abstract/2003/03000/ Compliance_With_Saliva_Sampling_Protocols_.19.aspx. DOI: 10.1097/01.PSY.0000058374.50240.BF

43. Adam EK, Kumari M. Assessing salivary cortisol in large-scale, epidemiological research. Psychoneuroendocrinology [Internet]. 2009 Nov; [cited 2016 Dec 2]; 34(10):1423-36. Available from: http://www. psyneuen-journal.com/article/S0306-4530(09)00201-7/abstract. DOI 10.1016/j.psyneuen.2009.06.011 